\section{Sleepiness accidents}

Helga Peter

Marburg, Deutschland

\section{Definition}

Schläfrigkeitsbedingte Unfälle.
Siehe dazu

- „Tagesschläfrigkeit und Unfälle bei Obstruktiver Schlafapnoe"

- „Einschlafen am Steuer“

- „Einschlafen am Arbeitsplatz“

- „Unbeabsichtigtes Einschlafen“ 